\title{
Hubungan Tingkat Ansietas Terhadap Quality of life Pada ODHA
}

\section{Relation the level of anxiety with quality of life in people with $\mathrm{ODHA}$}

\author{
Wira Daramatasia ${ }^{1 *}$, Mizam Ari Kurniyanti ${ }^{2}$ \\ ${ }^{1,2}$ Program Studi Pendidikan Ners, STIKES Widyagama Husada Malang \\ Jalan Taman Borobudur Indah 3A, Kota Malang, Jawa Timur, Indonesia \\ *Corresponding author \\ Email: wira.daramatasia@widyagamahusada.ac.id
}

\begin{abstract}
Keyword :

AIDS,

Anciety,

$H I V$,

WHOQOLHIV

$B R E F$,

ZSAS

Background: HIV/AIDS is one of the worst pandemics, in addition to the physical impact psikososial that make fear. Increased anxiety can affect the quality of life in ODHA. Objectif : The research aims is to understand the anxiety in the quality of life of patients odha in peer support groups JCC+. Methods : This research using analytic observational with the approach of cross sectional. Respondents were 40 taken with purposive approach based on techniques of sampling from 367 responden that include in the criteria and ekslusi who join the KDS JCC. Quality of life ODHA assessed using a questioner WHOQOLHIV $B R E F$, anxiety levels measured by the questionnaire zung self-rating anxiety scale (ZSAS). Data analysis using spearman test to test relation between levels of anxiety with Qol with the level of significance $5 \%$.. Results: The results of research related to the quality of life based on 6 ODHA, domain to have enough physical domain category of 52,5\%, psychological domain have good category of $75 \%$, the domain independence have quite as much as $70 \%$, category domain have enough social category of 52,5\%, the domain ward having good category of 52,5\% religious and spiritual domain / having good category of $70 \%$. The anxiety on the majority of 85 odha \% is categorized as a mild anxiety.There is a significant relation exists between the level of anxiety with a domain ODHA quality of life. Conclusion : The conclusion of a significant relation exists between the level of anxiety in the quality of life of the majority of 85 odha.tingkat anxiety on odha \% is categorized as a mild anxiety. There is a significant relation exists between the level of anxiety with a domain odha quality of life $(r 1=-0,1258, r 2=-0,1144, r 3=-0,0533, r 4=-$ $0,1258, r 5=-0,1398$, dan $r 6=-0,0609)$. The conclusion of a significant relation exists between the level of anxiety by odha quality of life.
\end{abstract}

Kata kunci :

AIDS,

Anciety,

HIV, WHOQOLHIV

BREF,

ZSAS

\section{A B S T R A K}

Latar belakang: HIV/AIDS merupakan pandemi yang paling buruk, hal ini dikarenakan berdampak tidak hanya pada fisik saja tetapi juga pada beban psikososial yang menyebabkan cemas. Peningkatan ansietas dapat mempengaruhi quality of life pada ODHA(Orang Dengan HIV AIDS). Tujuan: Penelitian ini bertujuan untuk mengetahui hubungan tingkat ansietas dengan quality of life pasien ODHA di kelompok dukungan sebaya JCC+. Metode: analitik observasional adalah metode yang digunakan dan Cross Sectional adalah pendekatan yang digunakan. Responden berjumlah 40 orang yang diambil dengan pendekatan Purposive Sampling dari 367 anggota yang ada di KDS JCC serta penuhi kriteria inklusi serta ekslusi. Quality of life ODHA diukur memakai kuisioner WHOQoLHIV BREF, tingkat ansietas diukur dengan kuesioner Zung Self-Rating Anxiety Scale (ZSAS). Analisis data menggunakan uji Spearman untuk menguji hubungani antara tingkat ansietas dengan QoL dengan tingkat signifikansi 5\%. Hasil : Hasil riset tentang quality of life ODHA bersumber pada 6 domain: domain fisik mayoritas kategori lumayan sebesar 52, 5\%, domain psikologis mayoritas kategori baik sebesar 75\%, domain kemandirian mayoritas kategori cukup sebesar 70\%, domain sosial mayoritas kategori cukup sebesar 52, 5\%, domain area mayoritas kategori baik sebesar 52, 5\% dan domain spiritual/ religi mayoritas kategori baik sebesar 70\%. Bersumber pada total 6 domain, responden mempunyai quality of life kebanyakan baik sebesar 70\%. Tingkat ansietas pada ODHA mayoritas $85 \%$ masuk kategori cemas ringan. Kesimpulan: Adanya hubungan 
yang signifikan antara tingkat ansietas dengan domain quality of life ODHA ( $r l=-0,1258$, $r 2=-0,1144, r 3=-0,0533, r 4=-0,1258, r 5=-0,1398$, dan $r 6=-0,0609$ )

How to cite : Dara Daramatasia,W.\& Kurniyanti,M.A., 2021. Hubungan Tingkat Ansietas Terhadap Quality of life Pada ODHA.Journal of Islamic Medicine,5(2),71-82. https://doi.org/10.18860/jim.v5i2.11617

Copyright $\odot 2021$

\section{LATAR BELAKANG}

Acquired immunodeficiency syndrome (AIDS) merupakan suatu kondisi (sindrom) imunosupresif yang berkaitan erat dengan berbagai infeksi oportunistik, neoplasma sekunder, serta manifestasi neurologik tertentu akibat infeksi Human immunodeficiency virus (HIV). ${ }^{1}$ HIV/AIDS adalah salah satu masalah kesehatan masyarakat yang serius dengan dampak parah pada berbagai aspek kehidupan manusia. $^{2}$

Di dunia, terdapat 35 juta orang mengidap HIV/ AIDS. Tiap tahun 2,5 juta orang tertular oleh virus ini. ${ }^{1}$ Di Indonesia, penderita HIV/AIDS di JaTim terdapat di urutan awal secara nasional, sedangkan Kabupaten Jombang menduduki posisi kedua sehabis Kota Surabaya. Berdasarkan data yang dirilis Komisi Penanggulangan AIDS (KPA) Kabupaten Jombang, temuan kasus HIV-AIDS sebesar 1.002 kasus. Hasil temuan KPA mulai tahun 1999-juli 2016 tentang ODHA, ODHA di Jombang tersebar di 21 kecamatan, sebesar 569 terconfirm HIV, sedangkan 433 terkonfirm AIDS. Sekarang dari 1002 ODHA, terdapat 504 yang bertahan hidup. Dari sumber penularan, $37 \%$ memiliki riwayat datang ke lokalisasi. Total ODHA $80 \%$ terinfeksi melalui hubungan intim, dengan sebaran pengguna PSK 37\%, pendamping Risti 24\%, homoseksual $8 \%$, PSK $11 \%$, dan waria $3 \% .^{3}$

Hasil studi pendahuluan, di lembaga swadaya masyarakat Jombang Care Centre (JCC) yang merupakan kelompok dukungan sebaya (KDS) yang berada di kabupaten Jombang, berdasarkan hasil interview ketua JCC pada tahun 2017 banyaknya ODHA yang mendapatkan pendampingan mencapai
367 orang, tetapi juga masih banyak ODHA yang belum terdaftar dan mendapatkan pengobatan.

Ansietas adalah perasaan takut, khawatir, yang tidak menyenangkan yang sering disertai dengan kegelisahan, kelelahan, masalah konsentrasi, ketegangan otot, berkeringat, dan debaran jantung. ${ }^{4}$

$$
\text { Ansietas merupakan gangguan }
$$

kejiwaan umum yang dapat terjadi pada orang dengan HIV AIDS. Beban yang diderita ODHA karena gejala penyakit baik yang bersifat organik maupun sebab psikososial dapat menimbulkan rasa cemas. Ansietas yang ditimbulkan oleh berbagai faktor pada ODHA dapat mempengaruhi tingkat ansietas seseorang yang berdampak pada quality of life ODHA.

Quality of life (Quality of Life/QoL) adalah istilah yang populer digunakan untuk menyampaikan keseluruhan rasa kesejahteraan dan mencakup aspek-aspek seperti kebahagiaan dan kepuasan hidup secara keseluruhan. ${ }^{5}$ Penilaian QoL pada ODHA menggunakan kuisioner World Health Organization Quality of Life- BREF (WHOQoL BREF), WHOQoL BREF adalah instrumen yang dikembangkan oleh WHO khusus untuk mengkaji quality of life pada penderita HIV/AIDS. ${ }^{6}$ Rozy (2016) melaporkan bahwa untuk mengetahui bagaimana quality of life seseorang dapat diukur dengan penilaian akan kepuasan seseorang terhadap status fisik, psikologis, sosial, lingkungan, dan spiritual. Banyak faktor yang mempengaruhi QoL pasien ODHA dengan penyakit kronis yang menyertainya. ${ }^{5}$

Tingkat ansietas memiliki arti perasaan tidak pasti atau ketidakberdayaan. Ansietas pada ODHA lebih tinggi dari orang lain, dalam hal ini cemas diperlukan unuk 
mempertahankan hidup, namun apabila berlebihan maka akan menyebabkan quality of life seseorang menjadi rendah. ${ }^{7}$ Fenomena diatas menjadi dasar tujuan mengapa penelitian ini harus dilaksanakan. yang dipilih

digunakan. Responden berjumlah 40

\section{METODE}

Subyek penelitian ini adalah ODHA usia diatas 18 tahun atau sudah menikah, terdiagnosa positif terinfeksi HIV $\geq 6$ bulan, dan menjalani terapi ARV serta anggota KDS JCC+, dan telah menandatangani informed consent. analitik observasional adalah metode yang digunakan dan Cross Sectional adalah pendekatan yang

menggunakan Purposive Sampling. Quality of life ODHA diukur menggunakan kuisioner WHOQoLHIV BREF, tingkat ansietas diukur dengan kuesioner Zung Self-Rating Anxiety Scale (ZSAS). ${ }^{8}$

\section{HASIL PENELITIAN}

Sebaran Karakteristik Responden Penelitian

Tabel 1. Karakteristrik Responden pada Agustus-september 2018 (N=40)

\begin{tabular}{|c|c|c|c|}
\hline No & Karakteristrik Responden & $\mathbf{N}$ & $\%$ \\
\hline \multirow[t]{3}{*}{1} & Gender & & \\
\hline & - Laki-laki & 25 & 62,5 \\
\hline & - Perempuan & 15 & 37,5 \\
\hline \multirow[t]{4}{*}{2} & Umur & & \\
\hline & - $18-25$ tahun & 4 & 10 \\
\hline & - 26-45 tahun & 28 & 70 \\
\hline & - $>46$ tahun & 8 & 20 \\
\hline \multirow[t]{5}{*}{3} & Pendidikan & & \\
\hline & - $\mathrm{SD}$ & 7 & 17,5 \\
\hline & - SMP & 9 & 22,5 \\
\hline & - SMA & 17 & 42,5 \\
\hline & - $\mathrm{PT}$ & 7 & 1,5 \\
\hline \multirow[t]{3}{*}{4} & Pekerjaaan & & \\
\hline & - Bekerja & 21 & 52,5 \\
\hline & - Tidak bekerja & 19 & 47,5 \\
\hline \multirow[t]{4}{*}{5} & Pendapatan & & \\
\hline & - $<1$ juta & 21 & 52,5 \\
\hline & - 1 juta s.d 2 juta & 3 & 7,5 \\
\hline & - > 2 Juta & 16 & 40 \\
\hline \multirow[t]{5}{*}{6} & Marital & & \\
\hline & - Belum menikah & 13 & 32,5 \\
\hline & - Menikah & 18 & 45 \\
\hline & - Duda & 4 & 10 \\
\hline & - Janda & 5 & 12,5 \\
\hline \multirow[t]{5}{*}{7} & Lama Terdiagnosa & & \\
\hline & - 6 bulan-1 tahun & 7 & 17,5 \\
\hline & - $>1$ tahun-5 tahun & 29 & 72,5 \\
\hline & - $>5$ tahun-10 tahun & 3 & 7,5 \\
\hline & - $>10$ tahun & 1 & 25 \\
\hline \multirow[t]{6}{*}{8} & Cara penularan & & \\
\hline & - Free Sex & 24 & 60 \\
\hline & - Terinfeksi darah & & \\
\hline & - Pengguna jarum & 4 & 10 \\
\hline & - Homo/Lesbi & 1 & 2,5 \\
\hline & & 11 & 27,5 \\
\hline
\end{tabular}


Tabel 2. Sebaran Quality of life pada Domain ODHA Bulan Agustus-September 2018 (N=40)

\begin{tabular}{|c|c|c|c|}
\hline No & Karakteristik Responden & $\mathbf{N}$ & $\%$ \\
\hline \multirow[t]{4}{*}{1} & Domain Fisik & & \\
\hline & - $\quad$ Baik & 19 & 47,5 \\
\hline & - Cukup & 21 & 52,5 \\
\hline & - $\quad$ Kurang & 0 & 0 \\
\hline \multirow[t]{4}{*}{2} & Domain Psikologis & & \\
\hline & - Baik & 30 & 75 \\
\hline & - Cukup & 9 & 22,5 \\
\hline & - Kurang & 1 & 2,5 \\
\hline \multirow[t]{4}{*}{3} & Domain Kemandirian & & \\
\hline & - $\quad$ Baik & 12 & 30 \\
\hline & - $\quad$ Cukup & 28 & 70 \\
\hline & - $\quad$ Kurang & 0 & 0 \\
\hline \multirow[t]{4}{*}{4} & Domain Sosial & & \\
\hline & - $\quad$ Baik & 19 & 47,5 \\
\hline & - $\quad$ Cukup & 21 & 52,5 \\
\hline & - Kurang & 0 & 0 \\
\hline \multirow[t]{4}{*}{5} & Domain Lingkungan & & \\
\hline & - $\quad$ Baik & 21 & 52,5 \\
\hline & - $\quad$ Cukup & 19 & 47,5 \\
\hline & - Kurang & 0 & 0 \\
\hline \multirow[t]{4}{*}{6} & Domain Spiritual/Religi/Keyakinan & & \\
\hline & - $\quad$ Baik & 28 & 70 \\
\hline & - $\quad$ Cukup & 12 & 30 \\
\hline & - Kurang & 0 & 0 \\
\hline
\end{tabular}

Tabel 3. Sebaran Quality of life Responden Bulan Agustus-September 2018 (N=40)

\begin{tabular}{ccl}
\hline Quality of life & $\mathbf{N}$ & \% \\
\hline Baik & 28 & 70 \\
Cukup & 12 & 30 \\
Kurang & 0 & 0 \\
\hline & 40 & 100
\end{tabular}

Tabel 4. Sebaran Kategori Tingkat Cemas Responden Bulan Agustus-September 2018 (N=40)

\begin{tabular}{ccl}
\hline Kategori Tingkat Cemas & $\mathbf{N}$ & \% \\
\hline Normal & 2 & 5 \\
Cemas ringan & 34 & 85 \\
Cemas sedang & 4 & 10 \\
Cemas Berat & 0 & 0 \\
\hline & 40 & 100 \\
\hline
\end{tabular}

Tabel 5. Hubungan Tingkat Cemas Dengan Quality of life Setiap Domain Pada ODHA di JCC+ Kabupaten Jombang Bulan Agustus-September 2018 (N=40)

\begin{tabular}{|c|c|}
\hline \multirow{2}{*}{ Domain Quality of Life } & Tingkat Cemas \\
\hline & Korelasi $(r)$ \\
\hline Domain pisik & $-0,1258$ \\
\hline Domain fsikologis & $-0,1144$ \\
\hline Domain kmandirian & 0,0533 \\
\hline Domain sosial & $-0,1258$ \\
\hline Domain lingkungan & $-0,1398$ \\
\hline Domain spiritual/religi/keyakinan & $-0,0609$ \\
\hline
\end{tabular}




\section{PEMBAHASAN}

\section{Karakteristik Umum Responden Berdasarkan Jenis Kelamin}

Tabel 1 menyajikan karakteristik responden yang berpartisipasi dalam penelitian ini. Hasil penelitian terhadap ODHA di JCC+ berdasarkan jenis kelamin menunjukkan mayoritas responden yang paling banyak dalam penelitian ini adalah laki-laki yaitu berjumlah 25 orang $(62,5 \%)$, sedangkan perempuan berjumlah 15 orang $(37,5 \%)$. Hal ini juga sependapat dengan jumlah kasus HIV/AIDS yang dilaporkan oleh Dirjen PPPL dalam kajian epidemiologi HIV di Indonesia pada tahun 2011-2016 dengan rasio kasus HIV/AIDS antara lakilaki dan perempuan adalah $2: 1$. Berdasarkan penelitian yang dilakukan oleh Henni Kusuma (2016), ditemukan bahwa dari 92 responden, didapatkan yang paling banyak adalah laki-laki yaitu berjumlah 65 orang (70.7\%), sedangkan perempuan 27 orang (29.3\%). Dalam penelitian lain yang dilakukan oleh Fitri dan Fatwa (2017) didapatkan hasil mayoritas ODHA memiliki jenis kelamin laki-laki dibandingkan dengan perempuan, yaitu sebesar 56 orang (56\%). Hasil ini dikarenakan penderita HIV/AIDS lebih banyak laki-laki dibandingkan dengan perempuan dilihat dari data komulatif HIV/AIDS berdasarkan jenis kelamin pada tahun 1987-2014 bahwa laki-laki yang terkena HIV/AIDS lebih banyak dibandingkan perempuan. ${ }^{9}$

Setyoadi (2013), menyatakan ketika awal kejadian HIV/AIDS diketahui banyak teridentifikasi pada laki-laki homoseksual, selain itu diduga terdapat 3 juta laki-laki di Indonesia merupakan pelanggan PSP

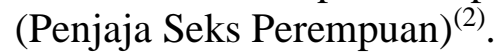

\section{Karakteristik Umum Responden Berdasarkan Usia}

Hasil penelitian menunjukkan paling banyak usia responden 26-45 tahun sebanyak 28 orang $(70 \%)$, hasil penelitian ini sesuai dengan penelitian Simanjuntak (2020) dimana didapatkan hasil rentang usia antara
26-45 tahun sebanyak 71.91\%. Usia responden yang cenderung lebih tinggi adalah pada kelompok usia 31-40 tahun yaitu 34 orang $(50,7 \%)$. Berdasarkan data tersebut, dapat disimpulkan bahwa infeksi HIV lebih banyak terjadi pada usia produktif. Hal ini terkait dengan perilaku beresiko yang memang lebih tinggi terjadi pada usia produktif yang disebabkan karena pada usia produktif memungkinkan lebih banyak melakukan perilaku seks tidak aman yang berisiko terhadap penularan HIV. ${ }^{4}$ Biasanya penderita tertular HIV/AIDS karena penyalahgunaan narkotika seksual dan hubungan seks bebas. Hal ini sesuai dengan proyek dan analisis tren epidemi yang sudah diperkirakan terjadi peningkatan pevalensi HIV pada populasi umur 15-49 tahun dari $0,21 \%$ pada tahun 2008 menjadi $0,4 \%$ tahun $2014^{8}$

\section{Karakteristik Umum Responden Berdasarkan Tingkat Pendidikan}

Dari hasil penelitian ini diketahui paling banyak responden tingkat pendidikannya adalah SMA sebanyak 17 orang $(42,5 \%)$. Data tersebut senada dengan penelitian Setyoadi (2013) menjelaskan bahwa rata-rata penderita HIV/AIDS berpendidikan SMA sebesar $46.3 \%$ dari total 67 responden. Penelitian lainnya oleh Simanjuntak (2020) di sebuah SMA menemukan bahwa $96 \%$ siswa pada tingkat pendidikan menengah atas dan tahu bahwa HIV menular melalui populasi heteroseksual, tetapi kebanyakan dari mereka menyatakan tetap melakukan hubungan seks secara tidak aman. Meskipun begitu penelitian tersebut tidak dapat dijadikan acuan bahwa tingkat pendidikan yang tinggi dapat melakukan tindakan pencegahan HIV. Data yang didapat menunjukkan bahwa tingkat pendidikan SMA adalah yang paling banyak sebesar 31 $(46,3 \%)$. Data tersebut ditunjang dengan RPPKI yang menjelaskan rendahnya pengetahuan masyarakat tentang HIV/AIDS dan data RISKESDAS 2010 menjelaskan terdapat $25,1 \%$ remaja yang mendapat penyuluhan tentang kesehatan reproduksi. ${ }^{1}$ 


\section{Karakteristik Umum Responden Berdasarkan Pekerjaan}

Responden dalam penelitian ini kebanyakan dalam status bekerja sebanyak 21 orang $(52,5 \%)$. Data tersebut sesuai dengan penelitian Indriani et al (2017) yang memaparkan responden dalam penelitiannya kebanyakan adalah Pekerja yaitu sebanyak 63 orang (63\%), bukan pekerja sebanyak 37 orang (37\%). Rozi (2016) dalam penelitiannya juga menyebutkan bahwa responden dengan status bekerja adalah mayoritas sebesar 30 orang $(68.2 \%)$ dibandingkan dengan yang tidak bekerja yaitu 14 orang $(31.8 \%)$ dari total 44 responden. Kejadian terinfeksi HIV/AIDS dapat dikaitkan dengan pekerjaan dimana seseorang memiliki pendapatan sendiri sehingga bisa melakukan segala hal termasuk free sex yang akhirnya terinfeksi HIV. ${ }^{10}$

\section{Karakteristik Umum Responden \\ Berdasarkan Penghasilan}

Responden dalam penelitian ini mayoritas memiliki penghasilan rendah yaitu dibawah Rp 1.000.000,00 sebesar 21 orang $(52,5 \%)$. Data tersebut sesuai dengan penelitian yang dilakukan oleh Harding At all (2014), hasilnya menunjukkan banyaknya responde yang berpenghasilan rendah lebih banyak terkena HIV yaitu sebesar 76 orang $(76 \%)$ dari total 100 orang responden. ${ }^{11}$ Penelitian lain yang dilakukan oleh Setyoadi (2013), didapatkan data yang hampir sama yaitu responden terbanyak memiliki penghasilan kurang dari 1 juta sebesar 20 orang $(29,9 \%)$. Ditjen PP dan PL Kemenkes RI 2014 memaparkan ekonomi merupakan resiko tinggi dapat menyebabkan orang masuk dalam perilaku berisiko menjadi PSK, LSL yang dapat menyebabkan terinfeksi HIV. ${ }^{1}$

\section{Karakteristik Umum Responden Berdasarkan Status Marital}

Responden dengan status menikah adalah yang terbanyak berdasarkan hasil penelitian ini yaitu sebesar 18 orang $(45 \%)$ sedangkan status lajang/belum menikah sebanyak 32,5\%. Data ini sesuai dengan penelitian Akinboro (2014), yang mendapatkan hasil responden terbanyak dengan status lajang/belum menikah sebesar $89.7 \%$, dan sudah menikah hanya $10.3 \% .^{12}$ Data yang sama juga didapatkan dari penelitian Kumar et al (2014) yang memaparkan bahwa responden paling banyak adalah yang belum menikah sebesar $57 \% .{ }^{13}$ Rozi (2016) menjelaskan kebanyakan responden yang masih lajang lebih sering berhubungan seks dengan PSK daripada yang telah menikah. ${ }^{5}$

\section{Karakteristik Umum Responden Berdasarkan Lama Terdiagnosa HIV/AIDS}

Data penelitian menunjukkan
responden dengan lama terdiagnosa HIV/AIDS pada rentang 1-5 tahun sebesar 29 orang $(72,5 \%)$. Hasil tersebut sesuai dengan Betancur (2017), yang memaparkan bahwa lama rata-rata penderita terinfeksi HIV yaitu $<5$ tahun. ${ }^{14}$ Kumar, et al (2014), menemukan data paling banyak responden yang terinfeksi HIV yaitu 2 tahun $(88.6 \%)$. Akan tetapi hal tersebut tidak dapat memastikan lama seseorang terdiagnosa HIV, sebab seseorang tidak akan bisa mengetahui secara pasti sebelum mereka periksa di RS. ${ }^{13}$

\section{Karakteristik Umum Subjek Penelitian ODHA Berdasarkan Cara Penularan}

Dalam penelitian ini mayoritas mengatakan cara penularan melalui hubungan intim sebanyak 24orang (60\%). Penelitian tersebut sesuai dengan Jamri et al (2018) 86\% responden mengakui melakukan hubungan free sex sebelum terkena HIV, dari data diatas dapat disimpulkan bahwa free sex termasuk salah satu cara penularan HIV/AIDS terbanyak. Dari Kompasiana menuliskan pada 2016 sebanyak 63\% remaja melakukan free sex di Indonesia. ${ }^{15}$ Dipaparkan juga kejadian tersebut berawal dari melihat gambar maupun vidio porno yang akhirnya menjurus ke perbuatan free sex yang akhirnya tertular HIV \& AIDS, disinilah pentingnya pendampingan dan 
pengawasan orang tua yang dapat mencegah terjadinya free sex dikemudian hari, tidak hanya itu saja peran guru juga sangat penting untuk bisa mengatur dan mengawasi pergaulan anak hingga remaja. ${ }^{10}$

\section{Gambaran Quality of life ODHA Berdasarkan WHOQoLHIVBREF Domain Fisik}

Hasil penelitian berdasarkan domain pada ODHA menunjukkan dari 40 orang, berdasarkan domain fisik terdapat 21 orang $(52,5 \%)$ mempunyai quality of life cukup, dan terdapat $47,5 \%$ memiliki quality of life baik serta tidak ada yang memiliki quality of life kurang.

Data tersebut menunjukkan adanya keluhan fisik seperti kelelahan, nyeri, kekurangan energi dan keterbatasan pergerakan tubuh tidak menganggu keseharian ODHA. Kebanyakan responden mengatakan tidak merasa terganggu dengan kondisi fisik karena HIV, dan kebanyakan mereka memiliki kepuasan tidur yang cukup. Dari data tersebut dapat disimpulkan bahwa penderita ODHA tidak terganggu istirahat dan tidurnya serta dapat melakukan kegiatan kesehariannya meskipun terdapat sakit di kondisi fisiknya.

Di tempat penelitian terdapat kegiatan rutin yang diadakan setiap satu bulan sekali, berupa pengajian, pertemuan terbuka/tertutup, kegiatan ringan bersama ODHA lainnya, adanya rutinitas meminum ARV, pemeriksaan fisik dan CD4. Terdapat kesesuaian antara data yang didapat pada penelitian ini dengan Setyoadi (2013) yang mengatakan bahwa terdapat 13 orang $(86,77 \%)$ yang menyampaikan bahwa mereka mendapat dukungan lebih banyak ketika bergabung dengan KDS, dan memiliki peran terhadap terapi ARV pada penderita ODHA.

\section{Gambaran Quality of life ODHA Berdasarkan WHOQoLHIVBREF Domain Psikologi}

Domain psikologi pada penelitian ini didapatkan mayoritas memiliki quality of life baik 30 orang $(75 \%)$, 9 orang $(22,5 \%)$ mempunyai quality of life cukup, 1 orang $(2,5 \%)$ mempunyai berquality of life kurang. Hal ini dikarenakan ODHA menjalankan kehidupannya sebagaimana orang normal pada umumnya, hal ini ditunjukkan dari jawaban subyek penelitian yang menikmati hidupnya dan merasa puas dengan dirinya sendiri, jarang merasakan putus asa, sedih, gelisah ataupun depresi. Dalam setiap kegiatan yang diadakan oleh KDS, subyek penelitian akan bertemu dan berinteraksi dengan sesama ODHA dan berbagi perasaan maupun informasi terkait penyakitnya. Peran KDS bagi ODHA adalah agar bisa merubah konsep diri responden agar bisa lebih baik lagi menerima kondisi penyakitnya dengan cara memberikan pengetahuan dan dukungan sehingga menimbulkan hal yang positif.

\section{Gambaran Quality of life ODHA Berdasarkan WHOQoLHIVBREF Domain Kemandirian}

Pada domain kemandirian didapatkan data terbanyak quality of life cukup sebesar 28 orang (70\%), 12 orang (30\%) mempunyai quality of life baik dan tidak terdapat ODHA dengan quality of life kurang. Hal tersebut dikarenakan kebanyakan ODHA merasa cukup mandiri dalam melakukan kegiatan sehari-hari maupun terapi ARV. Keteraturan terapi akan memberikan manfaat adanya peningkatan sistem imunitas, mengendalikan viral load, dan menunda progress dari penyakit HIV/AIDS, sehingga responden menjalani rutinitasnya tanpa kendala yang berarti. Hal ini sesuai dengan riset Debby at al (2019), bahwa ada terdapat hubungan keteraturan terapi ARV dengan quality of life pada kesehatan fisik dari ODHA. ${ }^{10}$

\section{Gambaran Quality of life ODHA Berdasarkan WHOQoLHIVBREF Domain Sosial}

Data hasil penelitian didapatkan domain sosial mayoritas memiliki quality of life cukup sebesar 21 orang (52,5\%), 19 orang $(47,5 \%)$ mempunyai quality of life baik 
dan tidak terdapat ODHA dengan quality of life kurang. Data tersebut menunjukkan segi sosial quality of life ODHA masuk dalam kategori cukup, mayoritas responden penelitian menjawab hubungan personal/sosial dengan keluarga maupun teman sebaya cukup dan memuaskan. Hal ini dikarenakan di KDS ODHA diberikan dukungan mental, saling bertemu dan memberikan dukungan, hal ini tidak hanya diberikan pada ODHA saja tetapi juga pada OHIDHA. Banyaknya stigma dan diskriminasi pada ODHA disebabkan pengetahuan mengenai HIV/AIDS sangatlah kurang.

Harapan diberikannya konseling pada OHIDHA diharapkan dapat merubah pemikiran sehingga tidak ada lagi ODHA yang dikucilkan, ditolak keluarga bahkan diusir dari rumah. Peran KDS adalah mengajak OHIDHA agar dapat untuk saling mengasihi, memotivasi, sehingga ODHA dapat menjalani kehidupannya lebih baik. Empati OHIDHA akan memberikan manfaat pada ODHA seperti merasakan hidup lebih berarti karena adanya dukungan tidak hanya dari keluarga saja tetapi juga dari teman maupun lingkungan tanpa adanya diskriminasi dan stgma. ${ }^{5}$

\section{Gambaran Quality of life ODHA Berdasarkan WHOQoLHIVBREF Domain Lingkungan}

Domain lingkungan pada penelitian ini memiliki quality of life baik sebesar 21 orang $(52,5 \%)$ mempunyai quality of life baik, 19 orang $(47,5 \%)$ mempunyai quality of life cukup dan tidak terdapat responden dengan quality of life kurang. Hal ini dikarenakan ODHA merasa cukup puas dengan adanya pelayanan yang diberikan baik dalam bidang kesehatan, tempat tinggal maupun adanya wadah komunitas untuk dukungan sebayanya diberbagai kabupaten/kota. Duriah (2014) menyatakan adanya tempat perlindungan, layanan kesehatan maupun wadah sosialisasi memiliki tujuan agar masyarakat mendapatkan pengetahuan lebih banyak terkait HIV AIDS sehingga tidak mendeskriminasi dan mau menerima keberadaan ODHA. ${ }^{5}$

\section{Gambaran Quality of life ODHA Berdasarkan WHOQoLHIVBREF Domain Spiritual/Religi}

Domain spiritual terbanyak masuk ke quality of life baik sebanyak 28 orang (70\%), 12 orang $(30 \%)$ mempunyai quality of life cukup dan tidak terdapat responden dengan quality of life kurang. Didapatkan mayoritas subyek penelitian menjawab hidupnya berarti dan tidak mengkhawatirkan masa depan akibat HIV/AIDS. Adanya kegiatan keagamaan rutin tiap bulan yang diadakan oleh KDS seperti pengajian, tausiah, serta merayakan hari hari besar keagamaan bertujuan untuk memberikan penguatan dan peningkatan keimanan kepada Tuhan yang Maha Esa bagi ODHA.

Kegiatan keagamaan yang dilakukan ODHA memiliki peranan untuk lebih memasrahkan diri kepada tuhan namun tetap berusaha untuk mendapatkan kesembuhan. Hal tersebut sejalan dengan penelitian Nuraeni (2012) yang menyatakan manajemen terapiutik secara berkelanjutan dan berdoa merupakan salah satu bentuk ikhtiar/usaha yang dapat dilakukan untuk mendapatkan kesembuhan. ${ }^{16}$

Efek samping akibat pengobatan dapat dialami oleh ODHA, selain itu juga kemngkinan dapat mengalami stigma dan diskriminasi dari masyarakat yang ada di lingkungannya. Masalah tersebut dapat mempengaruhi kesejahteraan ODHA baik fisik, psikologi, sosial dan ekonomi. Alasan inilah yang menjadi dasar bahwa pengobatan pada ODHA tidak hanya untuk memperpanjang hidupnya tetapi juga untuk meningkatkan quality of lifenya. ${ }^{17}$

Pasien yang mengalami HIV AIDS akan mengalami penurunan quality of life. Walaupun lebih banyak responden yang memiliki quality of life cukup, tetapi respon dari setiap responden berbeda-beda terhadap quality of lifenya tergantung persepsi dan keparahan penyakitnya responden. Hal itu 
tergantung pada kondisi fisik, kemandirian, sosial, spiritual dan peran keluarga. ${ }^{18}$

Banyak penelitian yang mengkaitkan masalah stres dan depresi dengan penyakit HIV/AIDS. Hal tersebut dipengaruhi oleh mekanisme koping yang digunakan oleh ODHA untuk beradaptasi dengan stressor. Adanya pendekatan masalah dan modifikasi perilaku dalam menghadapi stres akan jauh lebih baik dalam meningkatkan quality of life daripada ODHA yang tidak menggunakan keterampilan koping tersebut. ${ }^{13}$

\section{Gambaran Tingkat Ansietas ODHA}

Pada Tabel 4. hasil penelitian menunjukan prevalensi tingkat ansietas mayoritas 34 orang $(85 \%)$ masuk dalam kategori cemas ringan, hasil ini menggambarkan bahwa status ansietas ODHA di KDS JCC+ lebih rendah dibanding penelitian yang dilakukan oleh Enbal et al., 2012 diperoleh data sebesar $25 \%$ dalam kategori cemas ringan, demikian pula pada penelitian yang dilakukan oleh Celesia et al., 2013 diperoleh data sebesar 38\% masuk dalam kategori cemas ringan.

Data diatas menunjukkan bahwa ODHA memiliki respon adaptif yang positif melalui sistem limbik dan korteks cerebri. Ketika ODHA mendapatkan pembelajaran sebagai respon penerimaan diri maka persepsinya akan menjadi positif dan akhirnya perilaku ODHA dalam perawatan menjadi positif. ${ }^{3}$

Ansietas merupakan respon seseorang akan keadaan yang tidak mendukung dalam kehidupan sehari-harinya. Faktor fisik dan mental, keparahan penyakit, keadaan sosial dan ekonomi serta persiapan fisik mental sangat mempengaruhi tingkat ansietas pasien yang didiagnosis HIV AIDS. Keadaan status kesehatan dengan penyakit yang tidak dapat disembuhkan lagi mengakibatkan ansietas pada pasien tersebut. Dalam menjalani perawatan HIV AIDS setiap individu memiliki respon yang berbeda-beda, tergantung proses adaptasi individu yang dijalaninya sebagai salah satu sumber stressor baginya. ${ }^{7}$

\section{Hubungan Tingkat Ansietas dengan Quality of life ODHA}

Hubungan tingkat cemas dengan quality of life setiap domain pada ODHA di JCC + Kabupaten Jombang, berdasarkan analisis spearman menunjukan bahwa korelasi antara tingkat cemas dengan semua domain quality of life ODHA tersebut signifikan dalam interval keyakinan atau alpha 0,05 (Tabel 5). Korelasi antara tingkat cemas dengan domain fisik dari quality of life ODHA menunjukan hubungan negatif, dimana semakin rendah tingkat cemas ODHA maka semakin meningkat kondisi fisik.

Korelasi antara tingkat cemas dengan domain psikologis dari quality of life ODHA menunjukan hubungan negatif, dimana semakin rendah tingkat cemas ODHA maka semakin membaik kondisi psikologisnya, adapun kekuatan hubungan ini lemah $(r=$ $0,1144)$, pada domain psikologis mayoritas responden dalam kategori baik $(67,5 \%)$ masuk dalam tingkat cemas ringan.

Korelasi antara tingkat cemas dengan domain kemandirian dari quality of life ODHA menunjukan hubungan positif, dimana semakin tinggi tingkat cemas ODHA maka semakin meningkat kemandiriannya, adapun kekuatan hubungan ini lemah ( $r=$ $0,0533)$, pada domain kemandirian mayoritas responden dalam kategori cukup $(57,5 \%)$ masuk dalam tingkat cemas ringan.

Korelasi antara tingkat cemas dengan domain sosial dari quality of life ODHA menunjukan hubungan negatif, dimana semakin rendah tingkat cemas ODHA maka semakin membaik hubungan sosialnya, adapun kekuatan hubungan ini lemah $(r=-$ $0,1258)$, pada domain sosial mayoritas responden dalam kategori baik $(42,5 \%)$ dan cukup $(42,5 \%)$ masuk dalam tingkat cemas ringan.

Korelasi antara tingkat cemas dengan domain lingkungan dari quality of life ODHA menunjukan hubungan negatif, dimana semakin baik kondisi lingkungan ODHA 
maka semakin rendah tingkat ansietasnya, adapun kekuatan hubungan ini lemah ( $r=$ $0,1398)$, pada domain lingkungan mayoritas responden dalam kategori baik $(47,5 \%)$ masuk dalam tingkat cemas ringan.

Korelasi antara tingkat cemas dengan domain spiritual/religi dari quality of life ODHA menunjukan hubungan negatif, dimana semakin tinggi spiritual ODHA maka semakin rendah tingkat ansietasnya, adapun kekuatan hubungan ini lemah ( $r=-0,0609)$, pada domain spiritual/religi mayoritas responden dalam kategori baik $(62,5 \%)$ masuk dalam tingkat cemas ringan.

Hidup dengan penyakit HIV AIDS dapat melemahkan semangat, menakutkan dan menimbulkan ansietas. ${ }^{17}$ Ansietas dapat menyertai depresi atau dilihat sebagai gangguan dengan sendirinya, sering disebabkan oleh keadaan yang mengakibatkan ketakutan, ketidakpastian, atau ketidakamanan. ${ }^{19}$ Terutama di antara ODHA yang baru didiagnosis dengan HIV, ansietas telah terbukti lebih dominan di antara pasien dengan stres atau kelebihan stigma sosial yang terkait dengan diagnosis mereka. Telah diamati bahwa ansietas juga dapat berkorelasi dengan kepatuhan yang rendah terhadap terapi antiretroviral (ART) dan rekomendasi medis. ${ }^{10}$

Hasil penelitian ini sesuai dengan penelitian yang dilakukan oleh Chibanda (2016), ditemukan tanda-tanda depresi, ansietas dan stres terkait dengan skor yang lebih rendah di semua domain quality of life. ${ }^{20}$ Data menyatakan bahwa aspek fisik yang buruk QOL $(\mathrm{r}=0,90, \mathrm{p}=0,011)$ menyebabkan peningkatan depresi, ansietas $(\mathrm{r}=0,086, \mathrm{p}=0,013)$ dan stres $(\mathrm{r}=0,057, \mathrm{p}$ $=$ 037) gejala di antara ODHA dan sebaliknya. Pada aspek psikologis QOL, penelitian ini menunjukkan bahwa ODHA memiliki realisasi diri dari potensi mereka, berpikir positif, berusaha untuk menemukan makna dalam kehidupan, menjadi stabil secara emosional dalam keadaan sulit dan memiliki kemampuan untuk mengambil keputusan cenderung mengurangi ansietas dan sebaliknya. Oleh karena itu semakin tinggi QOL ODHA dalam aspek fisik, psikologis, kemandirian, menjaga hubungan sosial yang positif, lingkungan dan meningkatkan kegiatan spiritual akan membantu ODHA untuk mengatasi penyakit mereka, mengurangi ansietas dan sebaliknya. $^{12}$

\section{KESIMPULAN}

Demografi ODHA di KDS sebagai berikut, $62,5 \%$ berjenis kelamin laki laki, $70 \%$ berumur $26-45$ tahun, $42,5 \%$ pendidikan SMA, 52,5\% bekerja, 45\% menikah, 72,5\% terdiagnosa HIV/AIDS kurun waktu 1-5 tahun, $60 \%$ penularan melalui free sex. Ansietas ODHA 85\% masuk dalam kategori cemas ringan. Quality of life pada ODHA di KDS terbanyak $70 \%$ memiliki quality of life baik. Kesimpulan Adanya hubungan yang signifikan antara tingkat ansietas dengan domain quality of life ODHA

\section{UCAPAN TERIMA KASIH}

Ucapan terima kasih kami persembahkan kepada STIKES Widyagama Husada yang telah memberikan Hibah Penelitian internal untuk dosen, KDS JCC+ jombang, ODHA, maupun pihak lain yang telah membantu sehingga penelitian ini dapat terlaksana dengan baik.

\section{DAFTAR PUSTAKA}

1. Dinas Kesehatan Provinsi Jawa Barat. 2014. Rencana Strategis Dinas Kesehatan Provinsi Jawa Barat Tahun 2013-2018. Dinas Kesehatan Jawa Barat.

2. Setyoadi S. 2013. Pengalaman Odha Mendapatkan Dukungan Sosial Dalam Menjalani Kehidupan Sehari-Hari Di Malang Raya (The Experience of PLWHA Who Get Social Support Undergoing in Daily Life in Malang). Universitas Brawijaya.

3. Indriani SD, Fauziah N. 2017. Karena Hidup Harus Terus Berjalan (Sebuah Studi Fenomenologi Kehidupan Orang Dengan HIV/AIDS). Empati J Karya Ilm S1 Undip. 
4. Simanjuntak GV, Saragih M, Hasibuan EK, Pardede JA. 2020. Stop Stigma dan Diskriminasi ODHA. $J$ Abdimas Mutiara.

5. Rozi RF. 2016. Hubungan Dukungan Sosial Dengan Quality of life Odha Pada Kelompok Dukungan Sebaya Solo Plus Di Surakarta. Keperawatan.

6. Saxena DS. 2012. WHOQOL-HIV Instrument. World Heath Organ.

7. Shacham E, Morgan JC, Önen NF, Taniguchi T, Overton ET. 2012. Screening Anxiety In The HIV Clinic. AIDS Behav.

8. Rane MS, Hong T, Govere S, Thulare H, Moosa MY, Celum C, et al. 2018. Depression and anxiety as risk factors for delayed care-seeking behavior in human immunodeficiency virus-infected individuals in South Africa. Clin Infect Dis.

9. Unzila SR, Nadhiroh SR, Triyono EA. 2017. Hubungan Kepatuhan Anti Retroviral Therapy (ART) Satu Bulan Terakhir Dengan Quality Of Life Pasien HIV/AIDS Di Rsud Dr. Soetomo Surabaya. Media Gizi Indonesia.

10. Debby C, Sianturi SR, Susilo WH. 2019. Faktor-Faktor Yang Berhubungan Dengan Kepatuhan Minum Obat Arv Pada Pasien Hiv Di RSCM Jakarta. EJournal UMM.

11. Harding R, Simms V, Penfold S, Downing J, Namisango E, Powell RA, et al. 2014. Quality of life and wellbeing among HIV outpatients in East Africa: A multicentre observational study. $B M C$ Infect Dis.

12. Akinboro AO, Akinyemi SO, Olaitan PB, Raji AA, Popoola AA, Awoyemi OR, Ayodele OE. 2014. Quality of life of Nigerians living with human immunodeficiency virus. Pan Afr Med J. doi: 10.11604/pamj.2014.18.234.2816.

13. Kumar, Aswin \& Girish, H \& Nawaz, Ayesha \& Balu, P \& Kumar, B. 2014. Determinants of quality of life among people living with HIV/AIDS: A cross sectional study in central Karnataka,
India. International Journal of Medical Science and Public Health. 3(1) 10.5455/ijmsph.2014.230820142.

14. Betancur, M. N., Lins, L., Oliveira, I. R., \& Brites, C. 2017. Quality of life, anxiety and depression in patients with HIV/AIDS who present poor adherence to antiretroviral therapy: a crosssectional study in Salvador, Brazil. The Brazilian journal of infectious diseases : an official publication of the Brazilian Society of Infectious Diseases, 21(5), 507-514.

https://doi.org/10.1016/j.bjid.2017.04.0 04

15. Jamri, M.H., Hashim, N., \& Zolkepli, I.A. 2018. Stigma dan Diskriminasi Terhadap Orang yang Hidup Dengan HIV/AIDS (ODHA): Satu Pendekatan Tindakan Penyertaan Dalam Kalangan Belia di Pulau Pinang (Stigma and Discrimination Against People Living With HIV/AIDS (ODHA): A Participatory Action Approach Among Youth Circle in Penang). Jurnal Komunikasi: Malaysian Journal of Communication, 34, 55-74.

16. Marashi, T., Garg, S., Gupta, V. K., Singh, M. M., Sinha, P., Dewan, R., Ingle, G. K., \& Jiloha, R. C. 2009. Assessment of quality of life among HIV positive people attending tertiary hospital of Delhi, India. The Journal of communicable diseases, 41(2), 101-108.

17. Meemon, N., Paek, S. C., Yenchai, D., \& Wan, T. T. 2016. Application of the WHOQOL-HIV-BREF Questionnaire in HIV-Infected Thai Patients: Reliability and Validity of the Instrument. The Journal of the Association of Nurses in AIDS Care : JANAC, 27(5), 698-708. https://doi.org/10.1016/j.jana.2016.04.0 07

18. Dhakne, Supriya \& Dargar, Shivani \& Tawri, Pratik. 2018. Assessment of quality of life and its associated factors among people living with HIV/AIDS. HIV \& AIDS Review. 17. 134-141. 10.5114/hivar.2018.76371. 
19. Syed, I. A., Syed Sulaiman, S. A., Hassali, M. A., \& Lee, C. K. 2015. Assessing HIV and AIDS treatment safety and health-related quality of life among cohort of Malaysian patients: a discussion on methodological approach. Health expectations : an international journal of public participation in health care and health policy, 18(5), 13631370. https://doi.org/10.1111/hex.12116

20. Chibanda, D., Verhey, R., Gibson, L. J., Munetsi, E., Machando, D., Rusakaniko, S., Munjoma, R., Araya, R., Weiss, H. A., \& Abas, M. (2016). Validation of screening tools for depression and anxiety disorders in a primary care population with high HIV prevalence in Zimbabwe. Journal of affective disorders, 198, 50-55. https://doi.org/10.1016/j.jad.2016.03.00 6 